\title{
ROZWIJANA BRANŻA CZY SEKTOR BEZ PRZYSZŁOŚCI? MODERNIZACJA RYBOŁÓWSTWA BAŁTYCKIEGO PRL W LATACH 1970-1989 I JEJ WPŁYW NA LOKALNĄ SPOŁECZNOŚĆ PÓŁWYSPU HELSKIEGO
}

Streszczenie. Celem artykułu jest prezentacja wpływu państwowego, rybołówstwa bałtyckiego na społeczność Półwyspu Helskiego. W pierwszej części omówiono aspekty geograficzno-biologiczne mierzei oraz historię kształtowania się państwowego rybołówstwa na Morzu Bałtyckim w tym na opisywanym obszarze. W drugiej części wskazano zagadnienia związane z krystalizowaniem się poszczególnych podmiotów na Półwyspie Helskim oraz etapy modernizacji przedsiębiorstw państwowych i spółdzielni do 1989 r. Ostatnia część artykułu prezentuje wpływ rybołówstwa na lokalną społeczność, wskazując aspekty pozytywne i negatywne. Uzupełnienie stanowią losy prywatyzacyjne podmiotów oraz wpływ procesu restrukturyzacji na ludzi mieszkających na Półwyspie Helskim.

Słowa kluczowe: rybołówstwo bałtyckie, Półwysep Helski, kuter rybacki, rybołówstwo państwowe, spółdzielnia rybacka.

$\mathrm{P}$ ołożony na północy Polski, Półwysep Helski stanowił jedno z ważniejszych ogniw rybołówstwa na Morzu Bałtyckim. Rozmieszczone na jego obszarze porty i przystanie gwarantują rybakom swobodny dostęp do wydajnych łowisk ${ }^{1}$. Na przestrzeni lat 70. i 80. XX w. doszło do transformacji

${ }^{1}$ Półwysep Helski zapewnia dostęp do następujących łowisk pełnomorskich: „Za kamieniami” (dorsze, łososie), „Władysławowskie” (dorsze, śledzie, szproty, ryby płaskie), „Bronka” 
rybołówstwa, gdzie do czynników decydujących zalicza się stopniową automatyzację procesów i racjonalizację zatrudnienia. Okres późniejszy przyniósł przekształcenia prywatyzacyjne, które zmieniły branżę doprowadzając do całkowitej modyfikacji struktury własności i upadku większości podmiotów państwowych i spółdzielczych² ${ }^{2}$ Pod względem geograficznym obszar Półwyspu jest pasem ziemi, którego długość wynosi $35 \mathrm{~km}$, a szerokość waha się od $150 \mathrm{~m}$, w najwęższym punkcie, do około $3 \mathrm{~km}$ w najszerszym, obejmującym

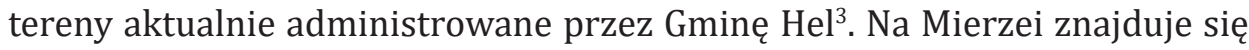
szereg miejscowości, w tym: dwa miasta (Hel, Jastarnia), dwie osady (Jurata, Kuźnica) oraz jedna wieś (Chałupy) ${ }^{4}$. Aktualnie na obszarze mieszają się wpływy ludności kaszubskiej (rodzimej) i napływowej.

Już w okresie zaboru pruskiego na Półwyspie realizowano inwestycje. Przykładem była budowa portu w Helu, który stanowił dogodną bazę jednostek łowczych ${ }^{5}$. Okres międzywojenny cechował się dynamiką rozwoju budowli hydrotechnicznych. Do użytku oddano porty w Jastarni oraz w Wielkiej Wsi, dzisiejszym Władysławowie, gdzie druga inwestycja była jedną z najważniejszych w regionie ${ }^{6}$. Rozwój został zatrzymany przez wybuch II wojny światowej. Po wyzwoleniu północnej Polski, nowe władze nie zrezygnowały z dalszego umacniania rybołówstwa na Półwyspie ${ }^{7}$. Podjęto akcję odbudowy

(dorsze, śledzie, śledziki, szproty, ryby płaskie), „I Kula” (dorsze w tarle luty-czerwiec, śledzie, płastugi, łososie), „II Kula” (dorsze w tarle luty-czerwiec, śledzie, płastugi, łososie), „NordOst” (dorsze, śledzie, śledziki, szproty, płastugi), „Krynica-Morska Ost” (dorsze, śledzie, śledziki, szproty, trocie), „Kamerun” (dorsze, śledzie, szproty), „Zatoka Pucka” (dorsze, śledzie, śledziki, szproty), „Kłajpedzkie” (JKSY) (dorsze, śledzie) oraz do następujących łowisk przybrzeżnych: „Karwia” (śledzie, śledziki, szproty, ryby płaskie), „Wielka Wieś” (śledzie, szproty, ryby płaskie, węgorze, trocie), „Hel” (dorsze, śledzie, węgorze, trocie, szproty, ryby płaskie), „Rewa-Mechelinki” (śledzie wiosną, słodkowodne, ryby płaskie, „Zatoka Pucka” (śledzie, szproty, węgorze, sieje, słodkowodne), „Orłowo-Sopot” (dorsze, ryby płaskie), „Górki Wschodnie” (śledzie wiosną, ryby płaskie, dorsze), „Krynica Morska” (śledzie wiosną, płaskie, dorsze). Zob.: W. Robakiewicz, Rybołówstwo morskie w małych portach, [w:] Materiały do monografii polskiego brzegu morskiego, Z. 2, Małe porty Pomorza Zachodniego w okresie 1945-1960, Gdańsk-Poznań 1962, s. 41-42.

2 AEK MIR (Archiwum Zakładu Ekonomiki Rybackiej Morskiego Instytutu Rybackiego w Gdyni) E. Kuzebski, Analiza przekształceń własnościowych i strukturalnych w państwowych przedsiębiorstwach połowowych, Gdynia 1995, [maszynopis niepublikowany] s. 15-16; S. Szostak, Polskie rybołówstwo 1990-1995, „Studia i Materiały” 1997, Seria E, nr 54, s. 7.

3 T. Piątkowski, Półwysep Helski. Informator krajoznawczy, Gdańsk 1988, s. 3.

4 Tamże, s. 47.

${ }^{5}$ D. Duda, B. Wandtke, Port Hel (Przyczynek do 100-letniej historii), Gdynia 1993, s. 11-12; H. Wünsche, Studien auf der Halbinsel Hela, Dresden 1901, s. 74-75; A. Ropelewski, Z historii helskiego portu, Gdynia 2011, s. 16-17.

${ }^{6}$ R. Białkowski, H. Gawlas, H. Spigarski, „Szkuner”, Port-Szkuner-Miasto, Gdańsk 2005, s. 18.

7 A. Ropelewski, Polskie rybołówstwo morskie, [w:] Polskie ziemie zachodnie i północne. Zagadnienia morskie, Poznań-Warszawa 1959, s. 35-36. 
i ulepszenia infrastruktury ${ }^{8}$. Obok struktur państwowych i spółdzielczych na Mierzei do końca PRL-u funkcjonowali rybacy indywidualni, jednak ich działalność była ograniczana przez komunistyczne władze. Funkcjonowanie rybołówstwa w $1986 \mathrm{r}$. prezentuje schemat 1.

\section{Schemat 1}

Elementy tworzące gospodarkę rybną w $1986 \mathrm{r}$.

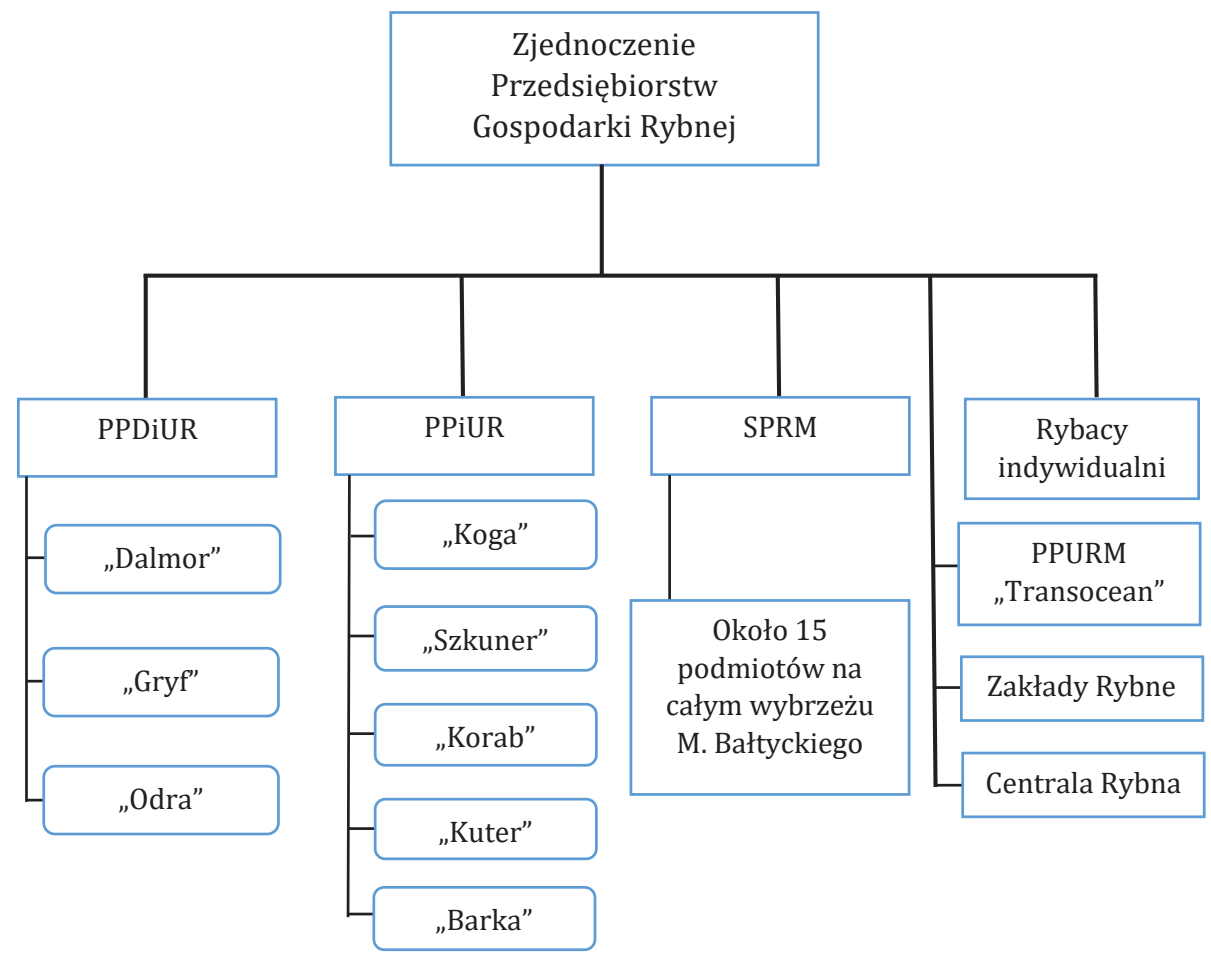

Źródło: Opracowanie własne na podstawie: Gospodarka rybna w latach 1986-1989, red. J. Grzenia, M. Gustowska, T. Jasińska i in., Gdynia 1991, tab. 48, tab. 109

W momencie tworzenia podwalin gospodarki centralnie planowanej, rybołówstwo na Półwyspie Helskim opierało się głównie o własność prywatną9. Od 1949 r. rozpoczęto proces nacjonalizacji majątku prywatno-spółdzielczego, zastępując go udziałami państwa. Przykładem takich działań

${ }^{8}$ Z. Ciesielski, S. Gierszewski, B. Kreja i in., Polska myśl morska, Gdańsk 1971, s. 132.

9 Morska gospodarka rybna PRL 1945-1985, red. W. Borowski, P. Bykowski, D. Dutkiewicz, i in., Gdynia 1989, s. 5. 
było Przedsiębiorstwo Połowów Dalekomorskich i Usług Rybackich (dalej: PPDiUR) „Dalmor” w Gdyni, które powstało jako wskazana wyżej inicjatywa, później znacjonalizowana ${ }^{10}$. Analogicznym podmiotem eksploatującym łowiska Morza Bałtyckiego było Przedsiębiorstwo Połowów Kutrowych (dalej: PPK) „Arka” z siedzibą w Gdyni, które posiadało swoje oddziały w niemal, każdym większym porcie bałtyckim ${ }^{11}$. Do 1959 r. na ich bazie stworzono pięć Przedsiębiorstw Połowów i Usług Rybackich (dalej: PPiUR) ${ }^{12}$. Funkcjonowanie rybołówstwa doby Polski Ludowej wzorowane było na sowieckich kombinatach, z różnicą ograniczonego dopuszczenia własności prywatnej. Taki system, z drobnymi zmianami trwał do około $1992 \mathrm{r}$.

W momencie powoływania poszczególnych oddziałów „Arki”, każdy z nich otrzymał niemal identyczne wyposażenie połowowo-przetwórcze. Tworzyły je: flota, hale przetwórni, hale manipulacyjne, fabryka lodu, myjnie opakowań, Armatorski Ośrodek Remontowy (AOR) lub Armatorska Stocznia Rybacka, składy opakowań, park maszynowy, budynki administracyjne oraz majątek nieprodukcyjny: mieszkania pracownicze, dom rybaka, stołówki, przedszkola, restauracje itp. ${ }^{13}$ Każdy z kombinatów posiadał cechy samodzielnego przedsiębiorstwa, które mogło funkcjonować w ramach gospodarki centralnie planowanej.

Rozwój państwowego rybołówstwa miał wpływ na ulepszenia infrastruktury technicznej na Mierzei. Przykładem były modernizacje portów w Helu i Jastarni oraz budowa niewielkiej przystani rybackiej w Kuźnicy. Przebudowano największy port we Władysławowie ${ }^{14}$. Dynamiczny rozwój branży był jedną z przyczyn migracji ludności do regionu. Dotyczyło to zwłaszcza Helu i Władysławowa, miejsc gdzie zlokalizowano przedsiębiorstwa połowowe $^{15}$. Dnia 1 stycznia 1955 r. z majątku kombinatu PPK „Arka” w Gdyni

10 AEK MIR, E. Kuzebski, Analiza przekształceń własnościowych..., s. 16; AEK MIR, J. Janson, Historia przedsiębiorstwa „Arka” w Gdyni (opracowanie z okazji 10-lecia istnienia), Gdynia 1959, [maszynopis niepublikowany], s. 10.

${ }_{11}$ AEK MIR, J. Janson, dz. cyt., s. 16, 18-19.

12 Do końca 1959 r. powołano do życia: PPiUR „Koga” w Helu, PPiUR „Szkuner” we Władysławowie, PPiUR „Korab” w Ustce, PPiUR „Kuter” w Darłowie i PPiUR „Barka” w Kołobrzegu.

${ }^{13}$ K. Podoski, A. Sobociński, Wybrane problemy rozwoju miasta Hel w latach 1920-1967, [w:] Dzieje Helu, Gdańsk 1967, s. 120; R. Białkowski, H. Gawlas, H. Spigarski, dz. cyt., s. 19; J. Kulikowski, Dzieje rybołówstwa morskiego w zarysie, Gdynia 1960, s. 235; A. Ropelewski, Polskie rybołówstwo morskie..., s. 39.

${ }^{14}$ R. Białkowski, H. Gawlas, H. Spigarski, dz. cyt., s. 19.

15 J. Narkowicz, Zgoda na czas dzisiejszy, [w:] Opowieść o trwaniu Kaszub, red. E. Szczesiak, Gdańsk 1985, s. 175-176; Wywiad z emerytowanym szyprem Mieczysławem Antoszkiem z 2 III 2013 [w kolekcji autora], s. 1. 
wydzielono PPiUR „Szkuner” we Władysławowie, które rozpoczęło samodzielną działalność ${ }^{16}$. W latach 60 . XX w. rozbudowano potencjał przetwórczy oraz uruchomiono fabrykę lodu łuskowego ${ }^{17}$. Przedsiębiorstwo otrzymało własną stocznię rybacką ze slipem do dokowania jednostek. Modernizowano port, jedną z najważniejszych baz rybołówstwa bałtyckiego. W latach 70 . XX w. rozpoczęto ulepszać park maszynowy. Przedsiębiorstwo wyposażono w maszyny do obróbki ryb pelagicznych „Arenco" SFD-300 oraz Seffelar ${ }^{18}$. W „Szkunerze” stale modernizowano urządzenia chłodnicze, co pozwoliło zwiększyć wydajność działów odpowiedzialnych za mrożenie ryby.

Wyodrębnione z gdyńskiej „Arki”, 1 kwietnia 1959 r. PPiUR „Koga” w Helu w początkowym okresie prowadziło ograniczoną działalność. Polegała ona na prostej obróbce surowca oraz skupie ryb od rybaków indywidualnych ${ }^{19}$. W latach następnych rozbudowywano infrastrukturę, skupiając się na poprawie warunków socjalno-bytowych. Od 1970 r. w przedsiębiorstwie rozpoczęto wprowadzać mechanizację procesów produkcyjnych, poprzez oddanie nowych linii obróbki dorsza (firmy Baader) i śledzia (Arenco SFD-300) oraz nowego budynku $\mathrm{AOR}^{20}$. W połowie lat 70 . XX w. oddano do użytku zaplecze zamrażalnicze oraz trzysegmentową chłodnię, która umożliwiła przechowywanie części wytworzonego asortymentu. Stale unowocześniano linie produkcyjne, które zostały częściowo dostosowane do produkcji eksportowej ${ }^{21}$. W dalszej perspektywie oddano magazyn podchładzany, budynek sieciarni oraz myjni opakowań22 ${ }^{2}$ Rozwijano też nadbudowę socjalną, która pozwalała pracownikom na uzyskiwanie mieszkań lub innych korzyści wiążących się z pracą w „Kodze”. Ostatnie modernizacje przedsiębiorstwa miały miejsce pod koniec lat 80. XX w., jednak w związku z rozpoczętym w 1990 r. procesem prywatyzacji nie wpłynęły one znacząco na dalsze funkcjonowanie kombinatu.

16 R. Białkowski, H. Gawlas, H. Spigarski, dz. cyt., s. 25.

17 Tamże, s. 37.

18 Tamże, s. 40.

19 AF PPiUR „Koga” (Archiwum Firmowe Przedsiębiorstwa Połowów i Usług Rybackich „Koga” w Helu), Biuletyn jubileuszowy PPiUR „Koga” w Helu 1979, Hel 1979, s. 3.

20 Tamże, s. 5-6.

21 AF PPiUR „Koga”, Biuletyn jubileuszowy PPiUR „Koga” w Helu 1989, Hel 1989, s. 8-9.

22 Tamże, s. 10. 
Tabela 1

Wielkość floty kutrowej eksploatowanej przez polskich armatorów na Półwyspie Helskim w latach 1970-1995 [szt.]

\begin{tabular}{|c|c|c|c|c|}
\hline \multirow{2}{*}{ Rok } & \multicolumn{4}{|c|}{ Liczba jednostek w eksploatacji [szt.] } \\
\cline { 2 - 5 } & $\begin{array}{c}\text { PPiUR } \\
\text { „Koga” }\end{array}$ & $\begin{array}{c}\text { PPiUR } \\
\text { „Szkuner" }\end{array}$ & $\begin{array}{c}\text { SPRM } \\
\text { "Gryf” }\end{array}$ & $\begin{array}{c}\text { Rybacy } \\
\text { indywidualni }\end{array}$ \\
\hline 1970 & 33 & 49 & 40 & 89 \\
\hline 1975 & 34 & 49 & 31 & 80 \\
\hline 1980 & 33 & 56 & 29 & 91 \\
\hline 1985 & 29 & 52 & 21 & 76 \\
\hline 1990 & 24 & 35 & 20 & 83 \\
\hline 1995 & - & 4 & - & 126 \\
\hline
\end{tabular}

Źródło: Opracowanie własne na podstawie: Gospodarka rybna w latach 1967-1995, Gdynia 1970-1998

Biorąc pod uwagę rozmieszczenie jednostek państwowych kombinatów na Mierzei Helskiej (tab. 1) widoczne są różnice dotyczące liczebności flot „Kogi” i „Szkunera”. Pierwsze z przedsiębiorstw przez cały badany okres dysponowało mniej licznym taborem pływającym, składającym się głównie z kutrów burtowych ${ }^{23}$. Drugi kombinat - „Szkuner”, został zaklasyfikowany do tzw. „przedsiębiorstw silnych”, co znajduje odzwierciedlenie w liczebności floty, w wyższym udziałem kutrów rufowych ${ }^{24}$.

W wypadku obu podmiotów uwidoczniła się tendencja do stopniowej redukcji jednostek znajdujących się w eksploatacji. Miało to związek z prowadzonymi pracami modernizacyjnymi we flotach. Analogiczna sytuacja wystąpiła we flocie Spółdzielni Pracy Rybołówstwa Morskiego (dalej: SPRM) "Gryf", która wraz z postępującymi uzupełnieniami zmniejszała swoją liczeb-

${ }^{23}$ Kutry burtowe - wszystkie prace manipulacyjne odbywają się na pokładzie roboczym umieszczonym w centralnej sekcji jednostki. Włoki trałowe wydaje się przez burtę (Gospodarka rybna w latach 1979-1981, „Studia i Materiały”, Seria E, nr 47, red. P. Bykowski, H. Ganowiak, J. Krępa i in., Gdynia 1986, s. 105; Morska gospodarka rybna PRL..., s. 103; zob.: Gospodarka rybna w latach 1986-1989, red. J. Grzenia, M. Gustowska, T. Jasińska i in., Gdynia 1991, tab. 48.

${ }^{24}$ Kuter rufowy - całość prac manipulacyjnych odbywa się na pokładzie umiejscowionym w rufowej sekcji jednostki. Włok trałowy wydaje się przez pochylnię znajdującą się na rufie kutra. Zob.: Gospodarka rybna w latach 1979-1981..., s. 106; Morska gospodarka rybna PRL..., s. 103; Gospodarka rybna w latach 1986-1989..., tab. 48. 
ność. Kasacja kutrów uznanych przez zarządy poszczególnych podmiotów za wyeksploatowane przełożyła się na wzrost udziału jednostek wykorzystywanych przez rybaków indywidualnych. kutry eksploatowane przez ostatnią z omawianych grup cechowały się najniższym stopniem automatyzacji procesów połowowych, co znajdywało odzwierciedlenie w uzyskiwanych wynikach ${ }^{25}$.

Na przestrzeni pierwszych 25 lat od zakończenia II wojny światowej obraz rybołówstwa nie uległ przeobrażeniom. Do połowów wykorzystywano głównie kutry burtowe, a stosowane metody produkcji cechowały się znikomym stopniem automatyzacji. Analogiczna sytuacja dotyczyła podmiotów gospodarujących na Mierzei Helskiej. W celu poprawy tak niekorzystnego stanu rzeczy Zjednoczenie Gospodarki Rybnej zdecydowało o wprowadzeniu w życie planu inwestycyjnego, który miał poprawić poziom zaawansowania technologicznego rybołówstwa.

Tabela 2

Skład flot poszczególnych przedsiębiorstw państwowych i spółdzielni rozmieszczonych na Półwyspie Helskim według stanu na 1989 r. [szt.]

\begin{tabular}{|l|c|c|c|}
\hline \multirow{2}{*}{ Typ kutra } & \multicolumn{3}{|c|}{ Udział kutrów we flocie [szt.] } \\
\cline { 2 - 4 } & PPiUR „Koga” & $\begin{array}{c}\text { PPiUR } \\
\text { „Szkuner” }\end{array}$ & SPRM „Gryf” \\
\hline 17m [B] & - & - & 14 \\
\hline KB/KŁ 21 [B] & - & - & 8 \\
\hline B-25s [B] & 6 & 5 & - \\
\hline B-25s/A [B] & 9 & 13 & - \\
\hline TR-27 [R] & 1 & - & - \\
\hline B-403 [R] & - & 9 & - \\
\hline B-410 [R] & 6 & 10 & - \\
\hline B-280 [R] & 3 & 1 & - \\
\hline
\end{tabular}

a $\mathrm{B}$ - kuter burtowy, R - kuter rufowy.

Źródło: Opracowanie własne na podstawie: Gospodarka rybna w latach 1986-1989, red. J. Grzenia, M. Gustowska, T. Jasińska i in., Gdynia 1991, tab. 4

${ }^{25}$ Morska gospodarka rybna PRL..., s. 131; Gospodarka rybna w latach 1986-1989..., tab. 48. 
Jednym z pierwszych elementów planu modernizacyjnego było wzmocnienie flot łowczych, co miało miejsce na przestrzeni lat 70 . XX w. W latach 1972-1976 wprowadzono do służby pierwsze zmodyfikowane kutry burtowe typu B-25s/A, które zasiliły floty państwowych kombinatów ${ }^{26}$. Łącznie wybudowano 62 jednostki. W drugiej fali modernizacyjnej do służby masowo wprowadzano kutry rufowe typu B-410 oraz B-403. Pierwsze z nich oddawano kombinatom na przestrzeni lat 1974-1983 w liczbie 65 szt. $^{27}$ Drugie w liczbie 14 szt. weszły w latach 1977-1979 w skład flot PPiUR „Szkuner” oraz PPiUR „Barka”28. Równolegle do realizowanych prac ze służby wycofywano kutry starszych typów przekazując je, jako wyeksploatowane, rybakom indywidualnym. Trzecia i ostatnia fala modernizacyjna flot przedsiębiorstw państwowych miała miejsce pod koniec lat 80 . XX w. Od 1988 r. rozpoczęto wprowadzanie do służby trawlerów rufowych typu B-280, których łącznie do 1993 r., oddano 18 szt. $^{29}$

Odmienna sytuacja miała miejsce w przypadku składu flot znajdujących się w eksploatacji SPRM. Zrzeszeni w podmiotach rybacy dysponowali mniej nowoczesnymi jednostkami połowowymi. Łącznie w trakcie analizowanego okresu przeprowadzono jedną modernizację flot, na którą składały się dwie serie jednostek. Pierwsze z nich otrzymały oznaczenie KB-21 (kuter burtowy) i wprowadzono je do służby w liczbie 21 szt. na przestrzeni lat 1978-198930. Analogiczne jednostki serii, określone jako KŁ-21 (kuter łososiowy) wprowadzano do służby w latach 1978-1982 w ilości 6 szt. głównie dla floty SPRM "Gryf” we Władysławowie ${ }^{31}$. W ramach prowadzonych modernizacji taboru pływającego znajdującego się w eksploatacji kombinatów połowowych, spółdzielnie otrzymały cztery kutry typu B-410 oraz pojedynczy trawler typu B-280. Poza wskazanymi zmianami nie realizowano żadnych innych programów modernizacyjnych.

Analizując połowy uzyskiwane przez poszczególne podmioty funkcjonujące w ramach gospodarki rybnej PRL i początku transformacji, można wyciągnąć wnioski dotyczące ich powiązania z poszczególnymi etapami modernizacji (tab. 3). Istotne były warunki meteorologiczne oraz wydajność biologiczna, które mają duży wpływ na połowy. Przykładowo na początku badanego okresu PPiUR „Koga” uzyskała poniżej 15 tys. ton surowca w skali

${ }^{26}$ W. Blady, Polska flota rybacka w latach 1921-2001. Kalendarium tragicznych zdarzeń na statkach rybackich w latach 1945-2001, Gdynia 2002, s. 75.

27 Tamże, s. 78, 80.

${ }^{28}$ Tamże, s. 81; M. Kubicki, Trawlery rufowe typu B-403 w polskiej, państwowej flocie kutrowej w latach 1978-1989, „Zapiski Puckie” 2019, z. 18, s. 145.

${ }^{29}$ W. Blady, dz. cyt., s. 83; J. Lisiecki, Założenia współczesnej polityki morskiej PRL i jej realizacja, [w:] Polityka morska państwa w 40-leciu PRL, Gdańsk 1986, s. 24.

${ }^{30}$ W. Blady, dz. cyt., s. 74.

31 Tamże. 
$\mathrm{roku}^{32}$. Wraz z procesem wdrażania nowych jednostek oraz podjętymi pracami modernizacyjnymi osiągane wyniki wzrosły do ponad 20 tys. ton ${ }^{33}$. Podobna sytuacja wystąpiła w PPiUR „Szkuner”. W badanym okresie połowy przedsiębiorstwa przekroczyły 35 tys. ton w skali roku ${ }^{34}$. Na wyniki w latach późniejszych miały wpływ spadek wydajności, efektywności oraz postępujący proces prywatyzacji kombinató $w^{35}$.

Biorąc pod uwagę przykład SPRM „Gryf” we Władysławowie, szczytowe momenty połowów przypadały na wprowadzenie do służby nowych jednostek $^{36}$. Okres późniejszy cechował się spadkiem uzyskania surowca, który wynikał z procesu dekompletowania majątku trwałego i obniżającej się kondycji biologicznej stad ryb, głównie dorsza. W rybołówstwie indywidualnym wyniki, wyłączając te osiągnięte w 1980 r., cechowały się niewielką zmiennością ${ }^{37}$. Było to związane $\mathrm{z}$ ograniczaniem rozwoju prywatnego kapitału w branży przez komunistyczne władz. Dodatkowo rybacy indywidualni nie mieli możliwości modernizacji eksploatowanego taboru, ze względu na prymat własności państwowej w rybołówstwie. Mogli nabywać tylko zdekompletowane jednostki, wyeksploatowane przez kombinaty lub spółdzielnie.

\section{Tabela 3}

Połowy floty kutrowej eksploatowanej przez polskich armatorów na Półwyspie Helskim w latach 1970-1992 [t]

\begin{tabular}{|c|c|c|c|c|}
\hline \multirow{2}{*}{ Rok } & \multicolumn{4}{|c|}{ Lączna wielkość połowów [t] } \\
\cline { 2 - 5 } & $\begin{array}{c}\text { PPiUR } \\
\text { „Koga” }\end{array}$ & $\begin{array}{c}\text { PPiUR } \\
\text { „Szkuner” }\end{array}$ & SPRM & $\begin{array}{c}\text { Rybacy } \\
\text { indywidualni }\end{array}$ \\
\hline 1970 & 13769 & 25262 & 6882 & 7756 \\
\hline 1975 & 22663 & 35319 & 8517 & 8533 \\
\hline
\end{tabular}

32 Morska gospodarka rybna w latach 1969-1971. Materiały do badań, „Studia i Materiały”, Seria E, nr 24, red. R. Maj, J. Kochanowski, J. Pietkiewicz i in., Gdynia 1973, s. 90.

33 Gospodarka rybna w latach 1979-1981..., s. 160.

34 Gospodarka rybna w latach 1975-1977. Materiały do badań, „Studia i Materiały”, Seria E, nr 43, red. B. Draganik, P. Bykowski, D. Dutkiewicz i in., Gdynia 1981, s. 124; Gospodarka rybna w latach 1979-1981..., s. 160; Morska gospodarka rybna PRL..., s. 141.

35 S. Szostak, Polskie rybołówstwo 1990-1995..., s. 8; AEK MIR, Z. Polański, Sytuacja polskiego rybołówstwa na Bałtyku (Nakład połowowy, połowy, efekty, limity), Gdynia 1991, s. 1.

${ }^{36}$ Gospodarka rybna w latach 1975-1977..., s. 160; Gospodarka rybna w latach 1986-1989..., tab. 48.

37 Morska gospodarka rybna w latach 1969-1971..., s. 90; Morska gospodarka rybna w latach 1973-1975. Materiały do Badań, „Studia i Materiały”, Seria E, nr 35, red. R. Maj, D. Dutkiewicz, H. Ganowiak i in., Gdynia 1978, s. 124; Morska gospodarka rybna PRL..., s. 141; Gospodarka rybna w latach 1979-1981 ..., s. 160. 
Tabela 3 (cd.)

\begin{tabular}{|c|c|c|c|c|}
\hline \multirow{2}{*}{ Rok } & \multicolumn{4}{|c|}{ Łączna wielkość połowów [t] } \\
\cline { 2 - 5 } & $\begin{array}{c}\text { PPiUR } \\
\text { „Koga” }\end{array}$ & $\begin{array}{c}\text { PPiUR } \\
\text { „Szkuner” }\end{array}$ & SPRM & $\begin{array}{c}\text { Rybacy } \\
\text { indywidualni }\end{array}$ \\
\hline 1980 & 21584 & 38566 & 8718 & 13742 \\
\hline 1985 & 15944 & 34548 & 3879 & 8943 \\
\hline 1990 & 5622 & 18784 & 1967 & $\cdot$ \\
\hline 1992 & 2912 & 7147 & 276 & $\cdot$ \\
\hline
\end{tabular}

Źródło: Opracowanie własne na podstawie: Gospodarka rybna w latach 1967-1995, Gdynia 1970-1998

Poczynione przez władze zwierzchnie inwestycje w rozwój państwowego rybołówstwa miały dwojaki wpływ. Analizując pozytywne oddziaływanie na Półwysep Helski, należy w pierwszej kolejności wymienić stymulację regionu, czego wyrazem był spadek bezrobocia oraz stopniowy wzrost zamożności, co dotyczyło zwłaszcza pracowników państwowych przedsiębiorstw ${ }^{38}$. Zwiększyła się liczba mieszkańców, co uwidoczniło się w przypadku Wielkiej Wsi, późniejszego Władysławowa, które uzyskało prawa miejskie w $1963 \mathrm{r}^{39} \mathrm{~W}$ tym samym roku odzyskał je Hel. Rozbudowano bazę socjalną, którą tworzyły: mieszkania zakładowe, świetlice, dom rybaka, a nawet przyzakładowe ośrodki zdrowia i żłobki ${ }^{40}$. Jedną z pozytywnych cech była konsolidacja lokalnej społeczności, biorącej udział w świętach takich jak: Dni Morza, Dzień Kobiet i inne. Przedsiębiorstwa i spółdzielnie organizowały refundowane wczasy zakładowe, gdzie istniała dalsza możliwość integracji pracowników. Występowanie prywatnej własności w rybołówstwie przyczyniło się do akumulacji kapitału i rozwoju bazy turystycznej, czego modelowym przykładem była i jest Jastarnia. Tak rozbudowana opieka państwa powodowała, że mieszkańcy regionu mieli poczucie bezpieczeństwa ekonomicznego i względnej stabilizacji.

Państwowe rybołówstwo miało również negatywny wpływ na Mierzeję Helską i jej mieszkańców. Do najistotniejszych czynników należy włączyć jednodziedzinowy charakter: „Szkuner” zrezygnowała tylko z utrzymania

${ }^{38}$ J. Narkowicz, dz. cyt., s. 176-177.

39 R. Białkowski, H. Gawlas, H. Spigarski, dz. cyt., s. 37.

40 AF PPiUR „Koga”, Biuletyn jubileuszowy PPiUR „Koga” w Helu 1989, Hel 1989, s. 6; AEK MIR, E. Kuzebski, Analiza przekształceń własnościowych..., s. 20. 
zbędnych, z punktu widzenia ekonomii, elementów majątku, konsolidując części odpowiadające za połowy i produkcję. Decyzja ta przyczyniła się do przetrwania przedsiębiorstwa. W PPiUR „Koga” proces wyprzedaży majątku zakończył się w 1998 r., a finalnie nowy nabywca ogłosił upadłość w 2001 r. i zakład zamknięto Po zaniechaniu połowów SPRM „Gryf” przebranżowiła się, zajmując się wyposażaniem jednostek rybackich oraz produkcją sieci.

Proces prywatyzacyjny w przedsiębiorstwach i spółdzielniach miał wpływ na lokalną społeczność. Skutkował wzrostem bezrobocia, co należy uznać za następstwo racjonalizacji zatrudnienia ${ }^{41}$. Poprzez skoordynowane działania zmniejszono liczbę pracowników. Wzrost stopy bezrobocia przyczynił się do pogłębienia ubóstwa wśród części z byłych zatrudnionych. Zlikwidowano osłony socjalne, które z punktu widzenia ekonomiki wolnego rynku, stanowiły obciążenie finansowe dla podmiotów. Proces restrukturyzacji miał też dobre strony. Należy do nich zaliczyć uwolnienie kapitału, co było następstwem prywatyzacji flot oraz części działów podmiotów ${ }^{42}$. Wystąpiła sytuacja, w której można było, posiadając niewielki kapitał własny, stworzyć podmiot gospodarujący. Pracownicy uzyskali możliwość wykupu mieszkań zakładowych, uznanych przez władze podmiotów za zbędne elementy generujące koszty ${ }^{43}$. Na bazie rozdzielanego majątku powstał szereg spółek, które częściowo lub w całości przejęły poszczególne działy produkcji oraz usług na rzecz restrukturyzowanych podmiotów. Przeprowadzone na przestrzeni niemal trzydziestu lat, procesy inwestycyjne, miały wpływ na lokalną społeczność i rozwój Półwyspu Helskiego. Wytworzono korzystne warunki dla rybołówstwa, jednak system miał szereg patologii, związanych z centralnym planowaniem w gospodarce rybnej. Spadek efektywności przypadający na koniec 80. XX w. podkreślił wszystkie złe cechy wytworzonego układu. Wpływ na rozwój regionu miała również rozpoczęta w 1990 r. prywatyzacja. W jej efekcie przetrwało tylko jedno przedsiębiorstwo PPiUR „Szkuner” we Władysławowie, a SPRM „Gryf” zmieniła specyfikę produkcji. W ramach przekształceń własnościowych uwolniono dużą grupę środków trwałych, która w przyszłości przyczyniła się do dynamicznego rozwoju regionu ${ }^{44}$. Aktualnie na Półwyspie Helskim główną gałęzią gospodarki jest turystyka, a rola rybołówstwa stopniowo maleje.

\footnotetext{
${ }^{41}$ AEK MIR, E. Kuzebski, Ocena efektów ekonomicznych..., s. 8; S. Szostak, dz. cyt., s. 8.

${ }^{42}$ AEK MIR, E. Kuzebski, Ocena efektów ekonomicznych..., s. 9.

43 Tamże, s. 10.

${ }^{44}$ S. Szostak, dz. cyt., s. 8.
} 


\section{BIBLIOGRAFIA}

\section{Źródła archiwalne}

Archiwum Firmowe Przedsiębiorstwa Połowów i Usług Rybackich „Koga” w Helu Archiwum Zakładu Ekonomiki Rybołówstwa Morskiego Instytutu Rybackiego w Gdyni

Biuletyn jubileuszowy PPiUR „Koga” w Helu 1979, Hel 1979.

Biuletyn jubileuszowy PPiUR „Koga” w Helu 1989, Hel 1989.

Janson J., Historia przedsiębiorstwa „Arka” w Gdyni (opracowanie z okazji 10-lecia istnienia), Gdynia 1959 [maszynopis niepublikowany].

Kuzebski E., Analiza przekształceń własnościowych i strukturalnych w państwowych przedsiębiorstwach połowowych, Gdynia 1995 [maszynopis niepublikowany].

Kuzebski E., Ocena efektów ekonomicznych zmian strukturalnych i własnościowych w państwowych przedsiębiorstwach połowowych, Gdynia 1996 [maszynopis niepublikowany].

Polański Z., Sytuacja polskiego rybołówstwa na Bałtyku (Nakład połowowy, połowy, efekty, limity), Gdynia 1991.

Russek Z., Opinia o prywatyzacji Przedsiębiorstwa Połowów i Usług Rybackich „Koga” Hel, Gdynia 1991.

\section{Źródła drukowane}

Ustawa z dnia 13 lipca 1990 r. o prywatyzacji przedsiębiorstw państwowych (Dz.U. nr 51, poz. 298).

\section{Źródła wywołane}

Wywiad z emerytowanym szyprem Mieczysławem Antoszkiem z 2 III 2013 [w kolekcji autora].

\section{Opracowania}

Białkowski R., Gawlas H., Spigarski H., „Szkuner”, Port-Szkuner-Miasto, Gdańsk 2005.

Blady W., Polska flota rybacka w latach 1921-2001. Kalendarium tragicznych zdarzeń na statkach rybackich w latach 1945-2001, Gdynia 2002.

Ciesielski Z., Gierszewski S., Kreja B. i in., Polska myśl morska, Gdańsk 1971.

Duda D., Wandtke B., Port Hel (Przyczynek do 100-letniej historii), Gdynia 1993.

Gospodarka rybna w latach 1975-1977. Materiały do badań, „Studia i Materiały”, Seria E, nr 43, red. B. Draganik, P. Bykowski, D. Dutkiewicz i in., Gdynia 1981.

Gospodarka rybna w latach 1979-1981, „Studia i Materiały”, Seria E, nr 47, red. P. Bykowski, H. Ganowiak, J. Krępa i in., Gdynia 1986.

Gospodarka rybna w latach 1986-1989, red. J. Grzenia, M. Gustowska, T. Jasińska i in., Gdynia 1991. 
Kubicki M., Trawlery rufowe typu B-403 w polskiej, państwowej flocie kutrowej w latach 1978-1989, „Zapiski Puckie” 2019, z. 18.

Kulikowski J., Dzieje rybołówstwa morskiego w zarysie, Gdynia 1960.

Lisiecki J., Założenia współczesnej polityki morskiej PRL i jej realizacja, [w:] Polityka morska państwa w 40-leciu PRL, Gdańsk 1986.

Morska gospodarka rybna PRL 1945-1985, opr. W. Borowski P. Bykowski, D. Dutkiewicz i in., Gdynia 1989.

Morska gospodarka rybna w latach 1969-1971. Materiały do badań, „Studia i Materiały”, Seria E, nr 24, red. R. Maj, J. Kochanowski, J. Pietkiewicz i inni, Gdynia 1973.

Morska gospodarka rybna w latach 1973-1975. Materiały do Badań, „Studia i Materiały”, Seria E, nr 35, red. R. Maj, D. Dutkiewicz, H. Ganowiak, i inni, Gdynia 1978.

Narkowicz J., Zgoda na czas dzisiejszy, [w:] Opowieść o trwaniu Kaszub, red. E. Szczesiak, Gdańsk 1985.

Piątkowski T., Półwysep Helski. Informator krajoznawczy, Gdańsk 1988.

Podoski K., Sobociński A., Wybrane problemy rozwoju miasta Hel w latach 1920-1967, [w:] Dzieje Helu, Gdańsk 1967.

Robakiewicz W., Rybołówstwo morskie w małych portach, [w:] Materiały do monografii polskiego brzegu morskiego, Z. 2, Małe porty Pomorza Zachodniego w okresie 1945-1960, Gdańsk-Poznań 1962.

Ropelewski A., Polskie rybołówstwo morskie, [w:] Polskie ziemie zachodnie i północne. Zagadnienia morskie, Poznań-Warszawa 1959.

Ropelewski A., Z historii helskiego portu, Gdynia 2011.

Szostak S., Polskie rybołówstwo 1990-1995, „Studia i Materiały”, Seria E, nr 54, Gdynia 1997. Wünsche H., Studien auf der Halbinsel Hela, Dresden 1901.

Mateusz Kubicki

\section{DEVELOPING INDUSTRY OR A SECTOR WITHOUT A FUTURE? MODERNIZATION OF THE BALTIC FISHERIES OF THE POLISH PEOPLE'S REPUBLIC IN THE YEARS 1970-1989 AND ITS IMPACT ON THE LOCAL COMMUNITY OF THE HEL PENINSULA}

Thest he article aims to present the influence of the state, Baltic fishing on the community of the Hel Peninsula. The first part discusses the geographic and biological aspects of the spit and the history of the state-owned fisheries in the Baltic Sea, including the described area. The second part indicates the issues related to the crystallization of individual entities on the Hel Peninsula and the stages of modernization of state-owned enterprises and cooperatives until 1989. The last part of the article presents the impact of fishing on the local community, indicating both positive and negative aspects. The privatization fate of entities and the impact of the restructuring process on people living on the Hel Peninsula are supplementary.

Keywords: Baltic fishery, Hel Peninsula, fishing boat, state fishing, fishing cooperative. 